\title{
Categorization of Urban Centres in Edo State, Nigeria
}

\author{
${ }^{1}$ Ojeifo .O. Magnus, ${ }^{2}$ Joseph O. Eseigbe \\ ${ }^{1,2}$ Department of Geography and Regional Planning Ambrose Alli University Ekpoma, Edo State, Nigeria
}

\begin{abstract}
This study examined the urbanization process of towns in Edo State. The major objectives were to determine the causes of urbanization of settlements in Edo State and also to categorize the urban centres according to their sizes. The objectives also identified the problems of urbanization in the state. Data for the study were collected from secondary sources including published books, articles in journals, student's thesis, and the census data of the National Population Commission. The data obtained by this means, were presented in tables. The study revealed that there has been a multiplication of urban centres in Edo State in the last 20 years, especially since 1991 and the creation of more local government councils and headquarters was responsible. It was also revealed that, the centres are urbanizing and population was the major factor of urbanization. Although, all the centres were urbanizing, the level of urbanization was found to vary among the centres, and it is upon this that the centres were categorized. Three categories of urban centres were identified for the state according to their population, they are, first, second and third order urban centres. The problems confronting the urban centres were identified to include, housing shortages, traffic congestion, decaying infrastructure and invasion of agricultural land.
\end{abstract}

Keywords - Categorization, Centres, Edo, Urbanization, Nigeria.

\section{Introduction}

Urbanization is a process of a city or urban growth. More appropriately, it refers to the percentage of a country's population living in urban areas (Clarke, 1975). In Africa, urban growth has been one of the most significant socio-economic developments that have taken place in the last fifty years. To this extent there has been an unprecedented transformation of many rural settlements into urban centres.

Using population index, only $14.54 \%$ of Africa's population lived in urban areas in 1950 . This rose to $18.15 \%$ in 1960 and $22.85 \%$ in 1970 . As at 1975 the proportion was $25.67 \%$ while in 1980 it rose to $28.85 \%$ (UNO, 1980). This statistics shows that there has been a progressive and steady urbanization of towns and cities in Africa. Several factors are attributed to this phenomenon, which include the need to establish centres of administration by colonial authorities; introduction of money economy and the general improvement of economy resulting from increase agricultural production and industrial development and the establishment of peaceful government (Clarke, 1975).

In Nigeria, urban growth is not a recent phenomenon. Since the emergence of ancient cities such as Benin, Kano and Zaria between the $14^{\text {th }}$ and $17^{\text {th }}$ century, there has been a steady evolution and multiplication of urban centres. The rate of multiplication however became greater from the 1960's with more urban centres emerging than before then. As at 1960 only four major administrative centres existed, these cetres were Lagos, Ibadan, Enugu, and Kaduna. By 1967, the centres rose to 13, while it became 21 centres in 1987. The centres again rose to 30 administrative state headquarters in 1991. Similarly administrative changes were undertaken at the local level resulting in the emergence of towns which are now headquarters of local government areas (Onokerhoraye and Omuta, 1994).

In the 1996 state and local government creation, the number of state administrative cetres increased to 36 while local; government headquarters increased to 774. It must be emphasized also that the Federal Capital Territory which was created as the nation's administrative headquarters has since emerge as urban centre. These administrative centres have over the years attracted commercial and industrial activities which has in turn encouraged immigration from rural areas to them thereby leading to rapid urbanization.

The 1950 estimated percentage of Nigeria's population living in the urban areas was $15 \%$. This rose to $23.4 \%$ in 1975 and 35\% in 1991. It is currently estimated at 46\% (Oluwasola, 2007). By the 2005 estimates, Nigeria has a population of 132 million. By this figure, approximately 60.7 million Nigerians are currently living in the urban areas. The rate of urbanization is $5.5 \%$ while the annual population growth is $3.0 \%$. Using the 132 million estimates of 2005 and the rate of urbanization, it is believed that more than half of Nigerian population will be living in urban centres by the year 2020 (Oluwasola, 2007). Urban growth and the rate of urbanization in Nigeria are attributed to several factors. First among them is the creation of new administrative centres in line with the desires and aspiration of the people. According to Mabogunje (1976) many African countries have experienced rapid urban growth as a result of post-colonial administration reforms. Another factor is economic expansion particularly the move towards industrialization while also was the restructuring of 
the space economy especially the development of a national system of urban centres for effective and equitable regional development (Onokerhoraye and Omuta, 1994).

Like many other settlements in Nigeria, settlements in Edo State are also fast urbanizing. The rapid growth in population and socio-economic activities of major towns of the area in recent years indicates this. In this study, settlements in Edo State are covered. The objective therefore is to identify and present in a map the urban centres in Edo State of Nigeria. This study is of importance because it will provide the much needed data for planning and development.

\section{Objectives and Methods of Data Collection}

The objectives of this study are to identify urbanizing centres in Edo state and examine the causes of urbanization of these centres. Also the study examined the factors responsible for urban growth and determined the categories of urban centres in the state. Urbanization problems affecting these centres were also examined.

Data for this study were obtained from secondary sources. These sources include published books and articles in journals and unpublished student's thesis. Data from these sources were used to enhance literature on urban centres. Also the population data of the study area for the 1963, 1991 and 2006 censuses were obtained from the National Population Commission Benin City. These population data were used in this study and presented in tables.

\section{The Study Area}

The study area is Edo State of Nigeria (shown in Fig. 1), which is made up of eighteen local government areas and divided into three senatorial districts of Edo North, Edo Central and Edo South Senatorial Districts. This area is located within latitude $5^{0} 30^{\prime}$ and $7^{0} 25^{\prime}$ north of the equator and longitudes $5^{0} 00^{\prime}$ and $6^{0} 50^{\prime}$ east of the Greenwich Meridian. The latitudinal location implies that this study area falls within the tropical region. The tropical climate is dominated by high temperature, high humidity and heavy rainfall. The area is characterized by two distinct seasons, the wet season which lasts between March and November and the dry season which lasts between November and February of each year.

The Ministry of Lands and Surveys, Benin City put the total land area of the state at $19,794 \mathrm{~km}^{2}$. It is situated on a relatively flat terrain devoid of plenty of rivers and it is approximately $466 \mathrm{~m}$ above the sea level. The 2006 national census put the population of Edo State at 3,233,366 people. Secondary and tertiary activities such as commerce, industry, social services are highly engaged in the area but the dominant occupation of the people is agriculture. This has been favored over time by the rich and well drained sandy loam which retains the advantage of good food and cash crop production. The vegetation is made up of forest in the south, savannah in the north and the mixed or derived savannah in the central part of the state.

Edo state is made up of several settlements most of which are rural. Several social and economic facilities are located, including electricity, industries, health and educational facilities, markets and transportation. However, most of these are located in the local government headquarters which are the major urban centres in Edo State and other few centres some of which are Ibillo, Otuo, Ihievbe, Agbede, and Okpella.

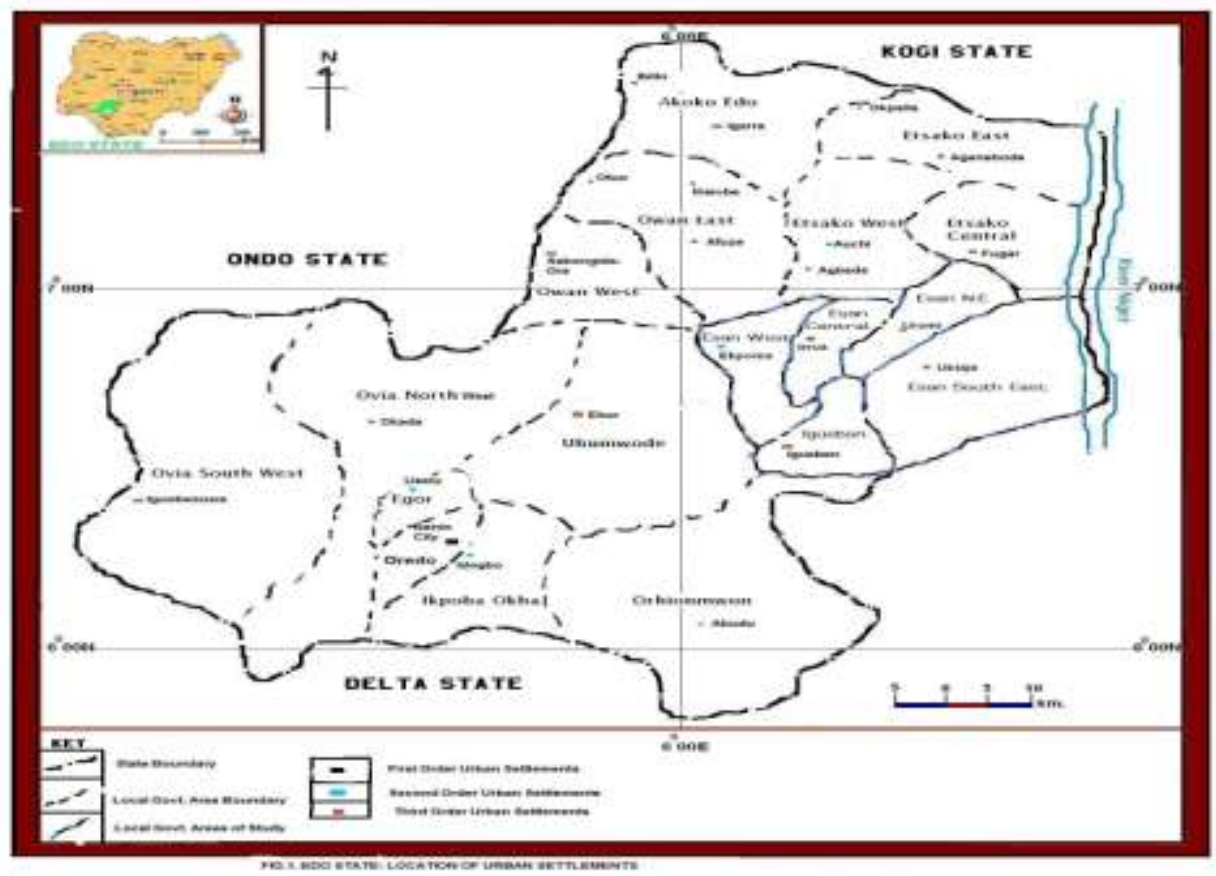




\section{Process of Urban Growth}

History has it that the Bini people have their origin with Ile-Ife but migrated to settle in Benin about the $7^{\text {th }}$ century. Due to several problems and interests such as institution of obnoxious laws by kings, several people migrated away from the Benin kingdom to settle in different locations. Among those that migrated between the14th-16 ${ }^{\text {th }}$ century A.D are the Esan people (Okojie, 1964), the Etsako's and the Owan people. Today the Edo people trace their origin to the Benin kingdom. Among the factors that made the migrating population to thrive in their eventual locations were availability of large expanse of fertile land, luxurious vegetation and favourable climatic conditions. While Benin itself was growing into a larger settlement, the migrating settlements evolved as isolated farmsteads and hamlets. With the passage of time some of the settlements developed into villages, but essentially they remained widely dispersed rural settlements even up to the 1960's. According to Olomo (1991), Esanland as at 1961 was without remarkable development as there were only few schools, markets, dispensaries and churches. Road network was poor, comprising few main and minor roads and several footpaths. The built-up areas were mainly along and by road junctions while most settlements were basically linear.

As at the early 1900, primary and secondary activities dominated the socio-economic landscape of this study area. While over $95 \%$ of the population at this time were farmers, small scale agro-based industries were the dominant industries. At this time also Benin City had emerged as urban settlement (Onokerhoraye and Omuta, 1994). It was until about the 1950's to 1960's that some settlements began to emerge as towns. For example as district headquarters for colonial administration in the 1950's Ubiaja and Auchi became emerging towns.

Over time and with favorable socio - political factors, more settlements emerge as towns. By the late 1970's and 1980's settlements such as Ekpoma, Afuze, Ubiaja, Abudu, Iguobazuwa, and Igarra emerged as major towns following their creation as headquarters of local government councils. These towns became centres of social and economic activities as facilities such as schools, health, roads, markets, electricity and water were established and expanded. Though economic activities were predominantly primary, secondary activities also featured prominently, examples are vulcanizing, vehicle repairs, transportation, sawmill, furniture, electrical and electronic, bicycle repair and bakery.

More towns emerged in the 1990's. In 1991, settlements such as Irrua, Sabongida Ora, Uromi, and Okada were made local government headquarters while in 1996, settlements such as Igueben, Agenebode, Fugar, towns were also made local government headquarters. Apart from these, few other settlements also emerged as towns during this time as a result of their prominence in agricultural and commercial activities. Examples are Okpella, Agbede, and Ibillo.

\section{Urbanization of the Study Area}

Among the criteria for defining urban settlement is population threshold, functional characteristics and legal and administrative definition. Using the population criteria, the United Nation's Economic Commission for Africa defined urban settlement as that settlements having a population of more that 20,000 inhabitants (Onokerhoraye and Omuta, 1994). Applying the 2006 population census figures, the settlements shown in Table 1 have been identified as urban in Edo State.

Table 1: Settlements and their Population (1963, 1991 and 2006 Census Figures)

\begin{tabular}{|c|c|c|c|}
\hline $\begin{array}{lll}\text { Esan } & \text { west } & \text { Local } \\
\text { Government Area } & \end{array}$ & $\begin{array}{l}1963 \\
\text { Population } \\
\text { figures }\end{array}$ & $\begin{array}{l}1991 \\
\text { Population } \\
\text { figures }\end{array}$ & $\begin{array}{l}2006 \\
\text { Population } \\
\text { figures }\end{array}$ \\
\hline Ekpoma & 34,948 & 61,408 & 77,483 \\
\hline $\begin{array}{l}\text { Esan Central Local } \\
\text { Government Area }\end{array}$ & & & \\
\hline Irrua & 18,088 & 24194 & 39,042 \\
\hline $\begin{array}{lll}\text { Esan } \quad N / E & \text { Local } \\
\text { Government Area } & \\
\end{array}$ & & & \\
\hline Uromi & 21,390 & 31,450 & 48.839 \\
\hline $\begin{array}{l}\text { Esan S/E Local Government } \\
\text { Area }\end{array}$ & & & \\
\hline Ubiaja & 8,480 & 21,030 & 28,100 \\
\hline $\begin{array}{l}\text { Igueben Local Government } \\
\text { Area }\end{array}$ & & & \\
\hline Igueben & 5,131 & 15,931 & 23,672 \\
\hline $\begin{array}{lll}\text { Akoko } & \text { Edo } & \text { Local } \\
\text { Government Area } & \\
\end{array}$ & & & \\
\hline Igarra & 9,513 & 24,940 & 33,891 \\
\hline
\end{tabular}


Categorization Of Urban Centres In Edo State, Nigeria

\begin{tabular}{|c|c|c|c|}
\hline \multirow{2}{*}{$\begin{array}{lll}\text { Ibillo } & & \\
\text { Owan East } & \text { Local } \\
\text { Government } & \text { Area } & \\
\end{array}$} & 7,900 & 18,471 & 24,303 \\
\hline & & & \\
\hline Afuze & 17.962 & 24,556 & 32,871 \\
\hline Otuo & 10,742 & 22,409 & 28,213 \\
\hline Ihievbe & 7,102 & 16,670 & 21.112 \\
\hline \multicolumn{4}{|l|}{$\begin{array}{l}\text { Owan West } \\
\text { Government Area }\end{array}$} \\
\hline Sabongida-Ora & 8,418 & 23,223 & 32,914 \\
\hline \multicolumn{4}{|l|}{\begin{tabular}{|lrl} 
Etsako West & Local \\
Government Area & \\
\end{tabular}} \\
\hline Auchi & 38,213 & 71.009 & 108,346 \\
\hline Agbede & 7,612 & 20,349 & 24,852 \\
\hline \multicolumn{4}{|l|}{$\begin{array}{l}\text { Etsako Central Local } \\
\text { Government Area }\end{array}$} \\
\hline Fugar & 4,502 & 18,319 & 23,193 \\
\hline \multicolumn{4}{|l|}{$\begin{array}{lll}\text { Etsako } \quad \text { East } & \text { Local } \\
\text { Government } & \text { Area }\end{array}$} \\
\hline Agenebode & 6,300 & 22,212 & 26,485 \\
\hline Okpella & 4,202 & 14,900 & 20,562 \\
\hline \multicolumn{4}{|l|}{$\begin{array}{l}\text { Oredo Local Government } \\
\text { Area }\end{array}$} \\
\hline Benin City & 100,694 & 780,976 & $3,218,332$ \\
\hline \multicolumn{4}{|l|}{$\begin{array}{ll}\text { Uhumwode } & \text { Local } \\
\text { Government Area } & \end{array}$} \\
\hline Ehor & - & 15,418 & 22,190 \\
\hline \multicolumn{4}{|l|}{\begin{tabular}{ll|} 
Orhiomwon & Local \\
Government Area &
\end{tabular}} \\
\hline Abudu & - & 21,349 & 26,773 \\
\hline \multicolumn{4}{|l|}{$\begin{array}{l}\text { Ikpoba-Okha } \quad \text { Local } \\
\text { Government Area }\end{array}$} \\
\hline Idogbo & - & - & 26,874 \\
\hline \multicolumn{4}{|l|}{$\begin{array}{l}\text { Ovia South West Local } \\
\text { Government Area }\end{array}$} \\
\hline Iguobazuwa & 4,491 & 21,738 & 26,300 \\
\hline \multicolumn{4}{|l|}{$\begin{array}{l}\text { Ovia North-East Local } \\
\text { Government area }\end{array}$} \\
\hline Okada & - & 14,919 & 25,479 \\
\hline \multicolumn{4}{|l|}{ 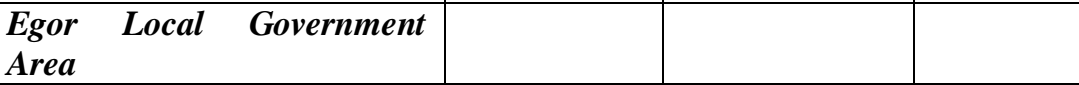 } \\
\hline Uselu & - & - & 142,934 \\
\hline
\end{tabular}

\section{Source: National Population Commission. Benin City 2010}

Note: (-) Not Available

The Table 2 shows that as at 1963, only 4 settlements were urban. The settlements are Benin City, Auchi, Uromi and Ekpoma. The census figures of 1991 show that number of urban settlements became 14 as at 1991. Settlements such as Sabongida-Ora Afuze, Irrua, Ubiaja, and Otuo emerged as urban settlements. The 2006 census figures revealed that more settlements emerged as urban as shown in column 4 of Table 2. Some of the settlements are Okada, Idogbo, Ehor, Okpella, and Fugar. As at this year also a total of 30 settlements became urban settlements in Edo state. Let it be noted that the population figures of some settlements could not be obtained partly because they were not readily available as at the time of this study and also because some of them were part of Benin City. Such settlements are Ugbor, Uselu and Idogbo.

In comparing the periods of urban emergence of settlements, it can be seen that only 4 or $17.4 \%$ of the settlements was urbanized as at 1963. As at 1991,10 or $43.4 \%$ of the settlements became urban settlements while 9 or $39.2 \%$ of the settlements also became urbanized as at 2006. Edo State has over 800 settlements. This study has shown that only 23 of the settlements are urbanized. According to Onibokun (1987), Nigeria is still predominantly a rural country as the majority still live in the rural areas. And within the sea of rural areas are a 
number of urban concentrations which are referred to as cities and metropolis. By this assertion, this study region is a sea of rural areas with a concentration of few urban centres.

\section{Categorization of Urban Centres in Edo State}

Based on the 2006 population figures, the urban centres in this study have been classed into three categories. The first category of urban centre is that with a population above 151,000 people. Only Benin City fall into this category and is therefore referred to as the first order urban centre in Edo State. Benin City is the Capital of Edo State and the headquarters of Oredo, and Egor local government areas. The second category of urban centres is those with population of 51,000-150,000 people. Uselu, Auchi and Ekpoma are the only settlements that fall into this class. They are therefore referred to as second order urban centres. The third category is those with population of 20,000-50,000 people. Irrua, Uromi, Igueben and Ubiaja, Okada, Fugar, Afuze, Iguobazuwa, Ihievbe and other settlements are in this category that can be referred to as third order urban centres. The categorization of the urban centres is shown in Table 2 and represented cartographically in Fig. 1. Let it be stated that 18 or $75 \%$ of the urban centres are local government headquarters while 6 or $25 \%$ of other centres that evolved as urban due to other factors such as natural increase, agricultural and commercial activities.

Table 2: Categorization of Urban Centres in Edo State

\begin{tabular}{|l|l|l|}
\hline First Order Urban Centre & $\begin{array}{l}\text { Second Order Urban } \\
\text { Centres }\end{array}$ & $\begin{array}{l}\text { Third Order Urban } \\
\text { Centres }\end{array}$ \\
\hline Benin City & Uselu & Irrua \\
\hline & Auchi & Ubiaja \\
\hline & Ekpoma & Igueben \\
\hline & Idogbo & Uromi \\
\hline & & Iguobazuwa \\
\hline & & Okada \\
\hline & & Ehor \\
\hline & & Agenebode \\
\hline & & Fugar \\
\hline & & Abudu \\
\hline & & Igarra \\
\hline & & Sabongida-ora \\
\hline & & Agbede \\
\hline & & Afuze \\
\hline & & Ihievbe \\
\hline & & Okpella \\
\hline & & Ibillo \\
\hline & & Otuo \\
\hline & & \\
\hline
\end{tabular}

Source: Field Survey, 2010

\section{Causes of Urbanization in the Study Area}

Several factors are responsible for urbanization in Nigeria. Some of these factors according to Onibokun (1987) are natural increase; the growth in size of government; rural-urban migration and spatial distribution of economic and social infrastructure. The factors identified to be responsible for urbanization in Edo State are many. For the purpose of this study, the factors considered most relevant are:

\section{(a) Natural Increase}

Natural increase arises from high birth rates due to increased marriages; desire to have more children, improved health facilities, education, personal hygiene and the provision social facilities such as water, electricity and roads. Urban centres in Edo State are centres of population concentration with high birth rates. This population is being sustained by improved health conditions due to personal hygiene, education and the provision of basic health and other socio-economic facilities such as hospitals, water, electricity, roads and schools in these centres.

(b) The Creation of Local Government Headquarters: As identified in this study, most of the urban centres are the local government headquarters. They are products of long term agitation for government at the local level. The emergence of these settlements as local administrative headquarters started in 1976. By the year 1991, the number of local government councils and their headquarters in Edo State had increased to 15 while it later became 18 in 1996. The exercise of local government creation has not only increased the number of 
Categorization Of Urban Centres In Edo State, Nigeria

settlements as local government headquarters but has transformed them to become urban centres of administration, economic and social activities and hence centres of population attraction.

\section{(c) Provision of Social and Economic Facilities}

Apart from Benin City, most urban centres were without basic social and economic facilities before 1961. Few earth roads, dispensaries, churches, post offices, markets and schools existed. Since 1976, tremendous infrastructural development has taken place. The creation of local government councils and their headquarters between 1976 and 1996 is a major factor in the location and expansion of infrastructures in the area. The councils needed to provide basic infrastructure in their headquarters for smooth administration and in the entire council areas for the overall welfare of its people. Notable infrastructure established especially in their headquarters includes hospitals, health centres, schools, markets, roads, drainages, electricity and water. The presence of these infrastructures has transformed these centres to become centres of growth and development.

\section{(d) Rural-Urban Migration}

Over the years Benin City and other local government headquarters and towns have witnessed tremendous influx of migrants especially from the rural areas. These migrants are attracted for reasons including seeking for jobs, education, health care, presence of infrastructure and other opportunities. The increase in population due to urban migration has brought about rapid urbanization of these centres. According to Okonigene (2008), three types of migrants are identified with the growth trend of these centres. The first are those migrants who have been employed directly in the services of facilities provided. The second types of migrants are those who are not employed but, came to utilize the opportunities offered by these facilities. The third type of migrants are those who by the reason of the presence of these socio-economic facilities have established ancillary activities, thereby employing not only themselves but creating employment for others and opportunities for more migrants. Some of the ancillary activities which migrants have established include electrical, mechanical, woodwork, transportation, medical, hotel, food, wears, and educational. These activities are very many and widespread and have a large migrant population employed in them.

\section{Problems of Urbanization}

Rapid urbanization of urban centres creates a number of problems. One of such problems is that of housing shortage. Due to high population concentration, urban houses have become inadequate thereby resulting in overcrowding, a situation where a large number of people are living together in a room or in an apartment that is insufficient for them (Omole 2001). Available studies show that about 50\% of households live in a single room in Nigeria urban centres (Ozo 1981). Also Sule (1994) identified that most of the urban centres have high occupancy ratio of 3 to 4 persons per room. Due to overcrowding, the housing environment in Nigeria is now characterized by huge refuse dumps, stagnant drains, dilapidated housing facilities and infrastructure and the emergence of squalor residences.

Studies in housing in some urban centres in Edo state show evidences of problems such as housing shortages, high rents, overcrowding and a wear down of some parts of the urban housing environment. A study carried out by Ufuah et al (2000) revealed that there is problem with housing in Benin City. The evidence of this was shown in the lack of accommodation and high occupancy ratio of 4 persons per habitable room. It was also identified that residents were not very accessible to social facilities such as water while refuse dumps littered the housing environment. The cause of these problems was attributed to rapid urbanization of the city especially the high population concentration. Ojeifo (2005) study on spatial quality of housing in Auchi showed evidence of the housing problems similar to that identified in Benin City. This study identified rapid population growth as the major causes.

Another problem is the rapid encroachment of physical development into agricultural and forest land. Study carried of the impact of urban emergence on the rural agricultural land of Ekosodin clearly shows that Benin City was rapidly encroaching into the agricultural land of Ekosodin (Ojeifo 2007). The cause of this was identified to be the high rate of physical expansion due to housing and infrastructural development. Rapid housing and infrastructural development was necessitated by the need to meet with the demands of the ever increasing population. Ojeifo (2007) identified the effects of this encroachment to include the cultivation of smaller farm sizes and movements to distant lands to farm.

Another problem of urbanization in Edo State is the lack of infrastructure and the overburdening of the few existing ones by the increasing population. Most urban dwellers do not have access to facilities such as roads, markets, schools, playground and health facilities because physical expansion created by population growth has outgrown places where the facilities are provided. For example it is common to see large areas of urban centres particularly new areas having no tarred streets, water, clinics and post offices. Also the evidence of overuse of the existing urban facilities by the increasing population is overwhelmingly clear. Most facilities have depreciated in quality while some are in state of disrepair because they are now been used by a population higher than the capacity they were meant for. In most urban area in Edo state increase in school enrolment, 
patient-doctor ratio, lack of access to water due to capacity of reservoirs, power outages due to transformer over loading and use of available space for the display of good in the markets are some examples to show the pressure that increase population is exerting on facilities. Because facilities are not often provided, expanded and maintained to meet with the increasing demand, majority of the urban population do not therefore have access to facilities.

Also important is the problem of haphazard use of urban land. Because most urban areas in Edo State do not have master plans or land use plans, land use development by individuals, government and private organization is being done haphazardly. Olomo (1991) identified that markets, shopping centres, houses, schools, parks and filling stations in Ekpoma were located haphazardly. Urban expansion due to population growth was identified to be responsible for this.

Another problem is traffic congestion. Rapid Urbanization brings about increased socio-economic activities. Increased activities are likely to generate high traffic. Most urban centres in Nigeria and Edo state are places of intense socio-economic activities. These activities generate inter and intra urban traffic. The level of vehicular traffic in some centres has become very high over the years and one problem that has become associated with it is the problem of congestion. In Benin City traffic congestion has become a menace. The study of Nzegwu et al (2008) shows that New Lagos road, Akpakpava, Ikpoba slope, Sapele, Ugbowo and Upper Mission roads are areas of heavy traffic congestion. Traffic congestion is also often witnessed in Auchi and Ekpoma urban centres.

\section{Conclusion}

This study has shown that settlements in Edo State have evolved over time with some now emerging as urban centres. It has also shown that the urbanization of these centres is attributed to several factors including, legal and administrative, population migration and the location of social economic infrastructure. However, as urbanizing centres, they do not possess the same physical and social economic characteristics. Using population characteristics, it is observed that some are more populated than others. On this basis therefore, these centres were categorized using the 2006 population census figures. Three categories of urban centres emerged, which are the first, second and third order urban centres. This means that three types of urban centres based on this study are found in Edo State. However, further research may be required on this to derive other possible ways of identifying urban centres in Edo State.

This finding is a veritable tool for government especially in the areas of physical and socio-economic planning. In terms of physical planning, it will afford government the opportunity to direct and control the utilization of land in its urban space so as to create a functionally efficient physical environment for its urban population. In terms of socio-economic planning, this study would not only help to determine the socioeconomic needs of the various urban centres, but also the location and distribution of the infrastructure to meet these needs based on their population sizes.

\section{References}

[1] J.I. Clark, Urban Geography, in J.I. Clark (Ed.), An Advanced Geography of Africa. (London: Hulton Educational Publication Ltd, 1975) 269-270

[2] United Nations, World Population Situation in 1979, UNO Population Studies, (72) 1980

[3] A. G. Onokerhoraye, G.E.D. Omuta, Urban Systems and Planning for Africa (Benin, The Benin Social Science Series for Africa, 1994).

[4] O. Oluwasola, Social Systems, Institutions and Structures: Urbanization, Poverty and Changing Quality of Life, Proc. of the training session of the foundation for environmental development and education in Nigeria, Port Harcourt, 2007,8

[5] A.L. Mabogunje, Cities and African Development (Ibadan, Ibadan University Press. 1976).

[6] C.G. Okojie, Esan Native Laws and Customs with Ethnographic Studies of Esan People, (Yaba, Okwessa and Co., Publishers, 1994).

[7] R.O. Olomo, Monitoring the development of Rural Area using remote sensing Approach: A case study of Ekpoma and Environs, Proc. $34^{\text {th }}$ Annual Conference of the Nigeria Geographical Association, Lagos, 1991, 10

[8] A.G. Onibokun, The policy Implication of Emerging Metropolises in Developing Countries, in A. Faninran, A Onibokun, and S.I. Abumere (Eds.), Urban and Regional Planning policy Formulation in Developing Countries. (Ibadan: Ibadan University Press, 1987) $91-92$.

[9] T. Okonigene, Socio-Economic Impact of Urban-Rural Migration. A Case Study of Ekpoma in Esan West Local Government Area, Edo State, post graduate diploma diss., Ambrose Alli University Ekpoma, Edo, 2008.

[10] F.K. Omole, Basic Issues in Housing development (Ondo, Femo-Bless Publications, 2001)

[11] O.A. Ozo, Housing Conditions of Urban Poor in Benin City, in P.K. Makinwa (Ed.), The Urban Poor in Nigeria. (Ibadan: Evans Brothers Publishers Ltd., 1981) 227-244

[12] R.O. Sule, Urban Housing in Nigeria, (Calabar, University of Calabar press, 1994).

[13] M.E. Ufuah, O.M. Ojeifo, M Uanikhoba, Analysis of Housing Quality and Problems in Oredo Local Government Area of Edo State, in S.O. Osuide (Ed.), Population Growth, Architecture and the Environment. (Iruekpen: Rasjel Publisher, 2005)169-183.

[14] O.M. Ojeifo, Analysis of the spatial Quality of Housing in Auchi, Edo State, The Built Environment Journal, 1(2), 2005,49 - 61.

[15] O.M. Ojeifo, Impact of Urban Emergence on the Rural Agricultural Land of Ekosodin, Confluence Journal of Environmental Studies, 2 (2), 2007, 74-82.

[16] M.A. Nzegwu, A.A.F. Banjo, W.Akhiwu, J.V Aligbe, C.O. Nzegwu, Morbidity and Mortality among Road Users in Benin City, Nigeria, Annals of African Medicine, 7(3), 2008, 102-106 